\title{
The Effectiveness of Tax Systems on Artisanal Miners and Small-Scale Miners
}

\begin{abstract}
Submitted 08/07/21, 1st revision 10/08/21, 2nd revision 25/09/21, accepted 18/10/21
Rumbidzai, P. Mutare ${ }^{1}$, Wadesango Newman ${ }^{2}$, Malatji Stephen Khashane ${ }^{3}$

Abstract:

Purpose: This desktop study was conducted in order to analyze the tax systems of artisanal miners. It sought to analyze the management of the tax systems with the view of improving the system and ensure that all participants in this sector are included in the tax bracket.

Design/Methodology/Approach: The study adopted a desktop research methodology. Data were collected from books, the internet and articles by scholars and other relevant sources. Findings: The results showed that paying taxes affect the artisanal miners negatively on their operations. It also emerged that the tax systems have failed to bring all the informal miners into the tax net. Hence there is a need to restructure the tax systems.

Practical Implications: Information and strategies to help the ASM sector must be put in place to increase awareness and increase tax compliance among this sector participant. ZIMRA can improve the flow of information by taking advantage of social media platforms such as WhatsApp and Twitter to disseminate information. Fliers and advertising campaigns can be used to spread information.

Originality/Value: It considers the fact that ZIMRA must provide incentives for compliant taxpayers as this will motivate them to continue being compliant and also push others to follow suit.
\end{abstract}

Keywords: Tax systems, artisanal miners, small-scale miners, developing country.

JEL codes: $C 1, C 4, C 5$.

Paper type: Research review.

\footnotetext{
${ }^{1}$ Midlands State University, Zimbabwe, rmutare@msu.ac.za;

${ }^{2}$ Prof, University of Limpopo, South Africa, newman.wadesango@ul.ac.za;

${ }^{3}$ Tshwane University of Technology, malatjiKS@tut.ac.za;
} 


\section{Introduction}

An artisanal miner is a miner who is not officially hired by a mining company who works independently mining different types of minerals or gold panning making use of their equipment and resources" (Gutu, 2017). ASM falls under the informal sector (Gutu, 2017). Furthermore, there is no assured definition of the informal sector due to many characteristics, and the International Labour Organisation (ILO) in its Kenya mission report in 1972 brought the theory of informal sector into international practice. According to ILO (1972) there are six features of the informal sector. These features are fully explained below.

"One of the features is that there is easiness in the entry because there are no major entry barriers as such anyone can enter into the informal sector and also there is too much dependence on indigenous resources because these are the only or maximum of the effective resources, they have access to" (Feige, 1994). "Similarly, most businesses in the informal sector are owned by families because they are usually small-scale operations" (ILO, 1972). "Another feature is that it is labour-intensive and includes adaptive technology because they have limited resources, they fail to raise enough capital, and most of the tasks are not difficult and can be performed without the use of heavy machinery" (Kuchta - Hebling, 2000). "Also, the skills executed in the informal sector are got outside the formal education" (Feige, 1994). Finally, "the informal sector works under free competitive markets meaning there is slight or no government participation on how the business operates" (Wadesango et al., 2020).

Feige (1994) asserts that "the informal sector like all other economic activities contribute to the GDP officially calculated but has unregistered individuals. He describes it as an economic activity which adds to the GDP of the country, but which is not registered with the government". Smith (1994) "informal sector is based on the production of goods and service delivery, legal or not that escapes the detection in the certified estimates of GDP." Hartzenberg and Lehmann (1992) say these are economic activities carried out without the permission of the governmental authorities, that is, those not included in the nation's accounts.

\section{Literature Review}

Tax is a payment to the state by an individual which is compulsory" (Wadesango et al., 2020). In TRA handbook (2008) "tax is an essential part of the government fiscal policy. Governments raise its revenue essential for meeting its public expenditure through taxation, and it is through these taxes that the government can finance its budget deficits". Mapunda (2020) says, citizens of a country have duties of paying taxes to enable the government to meet its costs of providing social and economic services. The government imposes a tax on either income, capital asset or expenditure from which the taxpayers do not benefit anything in return. Lymer and Oats (2009) postulate that the "equity principle illustrates tax systems have to be fair between 
individuals and they have to be charged basing on the taxpayer's ability to pay, and taxes are categorized into two groups namely direct and indirect taxes". Yilmaz and Coolidge (2013) say "direct tax means a load of taxation is endured completely by the individual or entity that has to pay for it, it is not possible to pass it to the next person or entity, as for example, corporate tax and individual's income tax. Indirect taxes are those taxes which are charged on goods and services that is, consumables, for example, value-added tax (VAT), sales and exercise taxes and other duties". Mansor et al. (2005) say "customers pay taxes indirectly in the form of high prices."

"Adam Smith found the four principles of tax that is equity, certainty, convenience and economy" (Tina, 2009). "His main concern in recommending the four principles was to increase the productive capacity of the economy, therefore attain high percentages of economic growth and achieve the reduction of costs of revenue collection thereby making it convenient to the taxpayer and the tax authority" (Bastable, 1903). "Other authors added more principles" (Tina, 2009). Such as "diversity, simplicity, flexibility, the productivity of revenue, social aims and competence also these principles are valid in this mining sector, though the emphasis of this sector suggests that some of them be seen in that setting and that more taxes be added" (Tina, 2009)

Chigumire et al. (2016) said, "the principle of equality says that the taxpayers should only pay taxes according to their abilities as determined by revenues that they obtain under the country's governmental protection." "Certainty requires the payee to know the tax liability, the timing and manner of payment in advance" (Tina, 2009). "Convenience requires that the timings and the modes of payments, that is, the tax administration has to be convenient to the taxpayers without fail and must not be made pointlessly hard or interrupt any business activities" (Chigumira et al., 2016). "Economy stresses out the need for reducing the revenue collecting costs. This canon is directly associated with the principle of simplicity that is tax systems have to be easy such that it is not difficult to understand and administer them" (Wadesango et al., 2020).

The revenue productivity principle is also closely linked with that of diversity, which says that the tax systems must have different means by which taxes can be collected so that a change in one form of collecting taxes will not affect the revenue that has to be collected (Tina, 2009). Otto et al. (2006), noted that the mixture of taxes has a benefit of stabilizing economic revenue through the stages of a mine. For example, import duties on capital goods imported produce income or returns during development, value-based royalties produce revenue during production, profit-based taxes produce revenue after a profit has been recognized. Additional tax only after the profit hurdle has been achieved. Similarly, some other types of taxes are not difficult to manage and avoid tax evasion. For example, royalty is centred on the amount produced or sold only (Otto et al., 2006). However, diversity affects the canons of economy and simplicity if too much emphasis is placed on it (Tina, 2009). 
Tax systems: The mining industry is taxed differently around the world as compared to other industries (Extract Industries Transparency Initiative, 2009) this is because their ways of operating their businesses are different from other economic entities (Otto et al., 2006) and social and environmental impacts are also different (Carels, Maroun and Padia, 2013) "this causes the government to increase charges in this sector (Extractive Industries Transparency Initiative, 2009). The burden of the mining industry taxes has been shielded basing on the fact that a country's minerals belong to its citizens and the mining participants should pay for the minerals that they are extracting as this will contribute to the society thereby benefiting the citizens (Otto et al., 2006). The African governments have seen that this is also linked to the point that colonization oppressed the citizens of their rights to minerals and due to this fact the mineral taxation is there to address these problems caused by colonization by allowing every member of the public to benefit from the country's mineral resources and also to raise revenue to the government (Maroun, Turner, and Sartorius, 2011; Mitchell, 2009; Mkandawire, 2010).

Theories of Tax Practices: Slemrod (2003) postulates that there is an increase in the amount of evidence from experiment studies that shows that citizens' trust in other people and by his/her observations trustworthiness of the government leads to equal tax assessment. Consequently, from these observation citizens are likely to pay taxes to the government only when they believe that the taxes will be used on their interests, the government's procedures are fair and reasonable and when their trust in the state and others is reciprocated Wadesango et al. (2020). Field (2006) claims that citizens are only willing to pay taxes voluntarily when the government has the capacity to provide goods and services otherwise, they will not comply. Voluntary tax compliance is a tax system that relies on citizens to report their revenues freely and voluntarily and to also calculate their tax liabilities correctly while filing a tax return on time (Kastlunger et al., 2009). Fagbemi et al. (2010) "it is a system whereby citizens inform the tax authority of the actual tax liability. It is used to refer to the willingness of citizens to abide by the country's tax laws, regulations and requests as provided by the tax management authorities. Gamboa (2002) argues that the main reason for poor revenue collection by the government and its agencies is due to corruption. Thought this is a reasonable contribution, there is a sense that revenue targets by the government are not realistic. It is important to have realistic revenue targets in enhancing the budgetary process as it serves as an effective performance standard which actual collection performance may be measured against (Chigumire, 2006).

Existing tax regimes: "This is the best way to spread the reach of the common formal sector taxation including income tax and VAT to reach the informal sector such as artisanal miners thereby formalizing their operations, and this can be done by recognizing the informal sector firms and making sure that they comply" (Bird and Wallace, 2003). The major drawback is that it leads to high administrative and compliance costs, particularly for small firms considering that they earn low revenues. This is only useful to larger firms as they can absorb the high compliance costs Wadesango et al. (2020). Thus, many governments in developing countries have 
decided to establish higher thresholds for income taxes and VAT to dismiss informal sector firms which will be catered for by the presumptive taxes, and other special taxes designed for the informal business (Keen, 2007; Wadesango and Mhaka, 2017). Withholding taxes have, however, been an exception as it is helping in collecting taxes from small firms and most developing countries use withholding tax on imports as a method to tax the informal sector (Keen, 2007).

\section{Discussion}

ZELA (2012) says, the mineral resources are limited that is why the governments end up charging more taxes and rentals whereas the natural resource is not extinct. "Several government agencies are involved in collecting mineral revenue, and these include, Ministry of mines and mining development (MMMD), Zimbabwe revenue authority (ZIMRA), Environmental management agency (EMA), Zimbabwe mining development corporation (ZMDC) and Minerals Marketing Corporation of Zimbabwe (MMCZ), (ZELA, 2012). This has brought worry to the government due to uncontrolled revenue collections and has compromised the feasibility of this industry, and there is no proper accountability and transparency when it comes to revenue collected from these minerals" (Mkandawire, 2010; Wadesango and Wadesango, 2016). The government is reviewing the mining taxation methods to address these challenges so that the country maximizes the proceeds from its mineral resources and encourages investment in the sector (ZELA, 2012).

The methods implemented in collecting revenue from ASM are described as: ZIMRA (2018) argue "in Zimbabwe the informal sector organizations such as the ASM pay VAT and duties but in this informal sector more revenue is collected through the use of presumptive taxes and this tax system was presented in Zimbabwe as an assisting tool to increase revenue collected by the revenue authority". The government removed presumptive tax system for ASM because it is said the tax burden was too high for them because they were also paying other taxes and levies. The government also removed the presumptive tax system as a way of encouraging the artisanal miner to formalize their operations in order to generate more revenue and with effect from the 1 st of October 2014 ASM presumptive tax was reduced from $2 \%$ of the gross amount payable to 0\%" (ZIMRA, 2018). ZIMRA (2018) argue this was done in order to incentivize the mining sector and motivating them to register and operate legally.

ZIMRA has since deployed other mining agencies to take part in collecting fees from artisanal miners whether registered or not registered, and these methods are said to be not effective as the artisanal miners are operating illegally on unregistered mining claims and are running away from paying taxes (Takavarasha, 2013). In the process, some artisanal miners have been arrested or imprisoned for illegally possessing gold because a lot of them operate unregistered claims (Takavarasha, 2013).

Challenges involved in bringing ASM into paying taxes: Most individuals are not willing to pay taxes as such, it has made it very difficult for revenue authorities from 
collecting revue (Alm et al., 2004). This is a huge challenge to all revenue collecting agencies around the country and the world at large because it is difficult to bring the individuals, firms, and activities into the tax net especially in the commonly wellknown hard to tax sector (the informal sector) (Alm et al., 2004). African Development Bank (ADB) (2005) says regardless of the implementation of the strategies aimed at simplifying the managerial procedures, increasing the tax base and encouraging equity and efficiency in the administration of tax no progress has been implemented in incorporating the artisanal miners into the tax net.

This sector is referred to as a cashed-based economy. The players are reliant on cash transactions. Some of them even go to the extent of refusing cheque payments and other paying methods which are not cash (Yihzhaki, 2012). This makes it possible for the enterprises to hide their actual profits and taxable income, and the informal sector players can manipulate their transactions for tax reduction purposes and sometimes do not reveal third party information on their records to evade taxes because cash transactions leave little or no audit trail (Wadesango et al., 2020).

Stella (1992) states that the informal sector players are not the only ones who make it challenging to tax this sector, but there are also administrative limitations that make it hard to tax the sector. Stella (1992) argues that tax administrations of many governments in Africa lack resources or workforce capacity to implement, monitor and enforce laws on taxation. Administration difficulties are seen as the main challenge for the authorities to collect revenues in general. In Zimbabwe, the informal sector takes almost $60 \%$ of all the economic activities, and the ASM also fall into this group. Therefore, there must be well-organized administration techniques that ensure tax compliance among the informal sector participants (Stella, 1992). In most cases, the staff are very few in Africa to the extent that they cannot cover the potential taxpayers in this sector. Also, the ASM sector is unique in its characteristics, which is another challenge in collecting tax from it (ZIMRA, 2018).

The impact of tax on ASM: Josh et al. (2013) assert that ASM are small in their operations as such concern was raised as to how the payment of taxes to the authorities will affect their day-to-day tasks and their subsequent survival. Yitzhaki (1994) indicated that paying taxes should not lead a business into bankruptcy. Vinish and Rajesh (2016) the paying of taxes affects most informal sector business performance negatively because there is a positive connection between poverty and the informal sector. The dualists have supported this is certain that the informal sector is made up of poor individuals who will be trying to make ends meet by taking part in the informal sector (Yitzhaki, 1994; Wadesango et al., 2016).

Josh et al. (2013) stated that imposing taxation on poor informal sector participants such as the artisanal miners will negatively hinder their growth. This will likely affect their cash flows, growth, and survival. Several studies have concluded that taxation on artisanal miners will possibly draw life out of their small operations. The profits made in this sector are meager and are not consistent so tax liabilities tend to be high 
to the extent that most of the individuals fail to pay their taxes and levies (Mkandawire, 2010). In support, Nyamwanza et al. (2014) say small to medium enterprises struggle to meet up with their tax liabilities which is made even worse by difficult penalties forced on them by ZIMRA and other collecting agencies.

However, the informal sector does not always receive low revenues or record low profits, but sometimes because of poor management, they misuse the funds and then fail to pay taxes (Mkandawire, 2010; Wadesango et al., 2017). Nyamwanza (2014) reiterated that "poor financial management among the players makes it difficult for them to add tax on their expenses if they cannot manage their day-to-day expenses." Mature et al. (2012) also say, "the informal sector businesses lack effective leadership skills to develop good strategic management, which is made worse by the statutory requirement to pay tax." Karuga (2013) said, taxation is a huge threat to the financial administration of small business operations.

\section{Conclusion}

The study concludes that the tax rates are too high for the so-called small-scale miners. In this regard, most of them desist from paying taxes because they feel that they are overcharged. "Many authors have pointed out that the informal sector intentionally keeps away from keeping proper books of accounts. However, in this study, the researchers found that they do not keep proper accounting records, instead, they lack the knowledge and skills. When they try to keep these records, they likely confuse them. This is the major reason why they fail to keep proper books of accounting".

\section{References:}

Ahmad, S.E., Stern, N.H. 1989. Taxation for developing countries. The London School of Economics.

Alm, J., Vazquez, J.M., Schneider, F. 2004. Sizing the Problem of the Hard-to-Tax. Atlanta: George State University.

Bird, R., Gendro, P. 2007. The Vat in Developing and Transitional Countries. Cambridge University Press: New York.

Bird, R., Wallace, S. 2003. Is It Really So Hard to Tax the Hard-to-Tax? The Context and Role of Presumptive Taxes, ITP Paper 0307, prepared for the International Tax Program Institute for International Business. Joseph L. Rotman School of Management University of Toronto, Toronto, Ontario.

Bird, R.M., Wallace, S. 2004. Is it really so hard to tax the hard-to-tax? The context and role of presumptive taxes. In: Alm, J., Martinez-Vazquez, J., Wallace, S. (Eds.).

Taxing the Hard-to-tax: Lessons from Theory and Practice (NorthHolland, Amsterdam), 121-158.

Bryman, B. 2007. The new role of the internal auditor: Implications for internal auditor. Canada Perspective. The Canadian Economic Observer, 7(5).

Caroll, E. 2011. Taxing Ghana's Informal Sector: The Experience of Women. Occasional Paper No.7, Christian Aid. 
Chidoko, C., Bemani, J., Matungamire, P. 2011. Tax law and practice in Zimbabwe: Concepts and Perspectives. LAP LAMBERT Academic Publishing GmbH \& Co.KG.

Embuka, A. 2015. Presumptive tax: Equalizing the distribution of tax burden (11) in Finance. News, 15(6).

Emran, S., Stiglitz, J. 2005. On selective indirect tax reform in developing countries. Journal of Public Economies, 89(4).

Engelschalk, M. 2005. Small business taxation in transition countries. The World Bank, Washington, D.C. 35109.

Feige, L. 1994. The Underground Economy and the Currency Enigma. Public Finances Publiques, 49, 119-136.

Fjeldstad, O.H., Heggstad, K.K. 2012. Building taxpayer culture in Mozambique, Tanzania, and Zambia: Achievements, challenges, and policy recommendations. CMI Report R 2012(1). Bergen: Chr. Michelsen Institute.

Gordon, R., Li, W. 2009. Tax Structures in Developing Countries: Many Puzzles and a Possible Explanation. Journal of Public Economics, 93, 856-866.

Hardon, A., Hodgkin, C., Freske, D. 2014. How to investigate the use of medicine by consumers. World Health Organization and University of Amsterdam.

Hart, K. 1973. Informal income opportunities and urban employment in Ghana. Journal of Modern African Studies, 11(3), 61-89.

Hartzenberg, M., Leimann, A. 1992. The Informal Economy and its Growth Potential in South Africa. Oxford: Oxford Press.

ILO. 1972. Employment, Incomes and Equality: A Strategy for increasing Productive Employment in Kenya. Geneva: ILO.

IMF. 2011. Revenue Mobilisation in Developing Countries. Washington DC: International Monetary Fund.

Joshi, A., Wilson, P., Heady, C. 2013. Taxing the Informal Economy; Challenges, Possibilities and Remaining Questions. IDS Working Paper 429. Institute of Development Studies.

Maloney, W.F. 2004. Informality revisited. In: World Development, 32(7), 1159-1178.

Sadka, E., Tanzi, V. 1993. A Tax on Gross Assets of Enterprises as a Form of Presumptive Taxation. Bulletin: International Bureau of Fiscal Documentation, 47(2), 66-73.

Saunders, M., Lewis, P., Thornhill, A. 2009. Research Business for Business Students: Fifth Edition. Harlow: Prentice Hall.

Thuronyi, V. 1989. Tax law design and drafting. International Monetary Fund.

Tokman, V.E. 1976. Competition between the Informal and Formal Sector in Retailing. The Case of Santiago World Development, 6(9), 10.

Tokmen, V.E. 2007. Integrating the informal sector in the modernization process. Retrieved from: https://www.un.org/en/ecosoc/meetings/2006/forum/Statements/Tokman.pdf.

Utaumire, B., Mashiri., E., Mazhindu, K. 2013. Effectiveness of presumptive tax system in Zimbabwe: Case of ZIMRA Region one. Research Journal of Finance and Accounting, 4(7).

Vinish, K., Rajesh, R.S.N. 2016. Do informal sector wages explain rural poverty? Evidence from India. Journal of Poverty, 20(1), 73-101.

Wadesango, N., Chinamasa, T., Mhaka, C., Wadesango, V.O. 2017. Challenges faced by management in implementing audit recommendations: A literature review. Risk Governance and Control: Financial Markets \& Institutions, 7(4), 51-61. 
Wadesango, N., Katiyo, E., Mhaka, C., Wadesango, O.V. 2017. An evaluation of the effectiveness of Financial Statements in disclosing true business performance to stakeholders in hospitality industry: A case of Lester-Lesley Limited. Academy of Accounting and Financial Studies Journal, 21(3), 1-22.

Wadesango, N., Mhaka, C. 2017. The effectiveness of enterprise risk management and internal audit function on quality of financial reporting in universities. Journal of Economics and Behavioral Studies, 9(4), 230-241.

Wadesango, N., Mhaka, C., Chinamasa, T., Wadesango, V.O. 2017. An investigation into management's reluctance in implementing audit recommendations and its effects to risk. Corporate Board: Role, Duties \& Composition, 13(2), 61-70.

Wadesango, N., Mhaka, C., Wadesango, V.O. 2017. Contribution of enterprise risk management and internal audit function towards quality of financial reporting in universities in a developing country. Risk Governance and control: Financial markets \& institutions, 7(2), 170-176.

Wadesango, N., Nani, L., Mhaka, C., Wadesango, V.O. 2017. An Analysis of the impacts of liquidity constraints on new financial product development. Risk governance \& control: Financial Markets \& Institutions, 7(3), 65-76.

Wadesango, N., Tasa, E., Milondzo, K., Wadesango, V.O. 2020. A literature review on the impact of IAS/IFRS and regulations on quality of financial reporting. Risk Governance and control: Financial markets \& institutions, 6(4), 102-108.

Wadesango, N., Wadesango, O. 2016. The need for financial statements to disclose true business performance to stakeholders. Corporate Board: Role, duties, and composition, 12(2), 77-84.

Wagner, J. 2005. Probability Vs Non-Probability Sampling. New York. Sage Publication.

Yilmaz, F., Coolidge, J. 2013. Can e-filling tax compliance costs in developing countries? Policy Research Working Papers.

Zikmund, W.G. 2000. Business research methods (2nd edition.). London: Harcourt. 